\title{
Gender, Affirmative Action, Human Rights and Equity: The Importance of Education of the Female in Nation Building
}

\author{
Mrs. Olugbemi Victoria Kikelomo; Mrs. Olugbuyi Adejoke Olumayowa \\ Department Of History and International Studies Adekunle Ajasin University, Akungba Akoko, Ondo State, \\ Nigeria \\ Department Of General Studies, Federal Polytechnic, Ado-Ekiti,, Ekiti State, Nigeria
}

\begin{abstract}
Nigeria is one of the countries where the female gender has not been able to make visible and valuable contributions to nation-building on equal pedestal with the male gender. The $35 \%$ affirmative action on women is yet to be realized in Nigeria. It grew worse during this 2011 April elections in Nigeria. This paper therefore, highlights the major causes of female gender's disparity with their male counterparts as cultural, religious and the impact of the British Colonial Government on Nigeria. The paper traces the way the British Female gender broke the barriers in Britain through the potent weapon of education \& then highlights the importance of formal and informal education to the female gender in Nigeria. The paper also trace some notable Nigerian women who broke the barriers through the acquisition of traditional and western education. Women like Mrs. Funmilayo Ransome Kuti, Mrs. Margaret Ekpo, Mallama Gambo Sawabo, Mrs. Ngozi Iweala, Professor Dora Akinyuli, Hon. Abike Dabiri-Arewa and others are mentioned. The conclusive part of the paper states that the importance of education to nation-building cannot be underestimated and it is very immeasurable especially when it is given to women, who are naturally nation-builders. Suggestions are made on how the government, the parents and the female themselves can make education available to the female gender so as to remove all the inhibitions, prohibitions and restrictions from every aspects of her life so that she can make a meaningful contribution to the building of her nation.
\end{abstract}

\section{Introduction}

In Nigeria today, the female gender is yet to participate fully with their male counterparts in the process of policy and decision making process. The percentage of the female in both appointive and elective positions in Nigeria is very low. Nigeria is a country endowed with human and natural resources, yet, Nigeria after fifty years of independence is still roaming in the corridor of underdevelopment and cannot take her rightful position among the World Committee of Nations. Recent research shows that many female genders lost to male gender in the elective and appointive participation in the governance of this nation, the female gender is less than the male. Some observers believed that many women who contested lost out because they are discriminated against by members of their communities ${ }^{1}$. Many women did not vote for their women counterparts as a result of barriers that are cultural, religious and western-oriented beliefs inherited during the colonial era. Some attributed the loss to the economic weakness of the female contestants. Others believed that women could not go to the extent which men went through to win election such as the use of thugs, giving empty promises to the electorates and membership of cultism ${ }^{2}$. The economy of Nigeria is still dwindling; there is no constant power supply, there are incessant tribal and religious crises as a reaction to unequal access to the nations' wealth. The recent political election did not give women the $35 \%$ affirmative action. In the last election, no woman was elected as President, only one deputy governor, seventeen House of Representatives and seven Senators were elected $^{3}$.The governmental business of the nation is marred with corrupt practices, embezzlement, nepotism and self-aggrandizement. Socially, there is mass unemployment, youth delinquency, prostitution and armed robbery. Culturally, Nigerian youths are fast loosing trends with their roots. The question which readily comes to mind is why are things the way they are in Nigeria? Where did things go wrong? And what happened in other parts of the world where the situation contrast the Nigeria situation? This paper is set to examine these questions which constitute great barriers to nation building in Nigeria.

The methodology adopted in this paper is primary and secondary sources. The primary source is largely oral interview while the secondary source depended on the written materials such as books, newspapers, conference materials and private papers. Attempt is also made to present a concise theoretical framework on the

\footnotetext{
${ }^{1}$ Oral information collected from Mrs Alonge 65years old, at Akure , a retired Banker,7/3/2011.

$20 \%$ of people interviewed in South-western Nigeria shared this view.

${ }^{3}$ Result of the April,2011 general election results
} 
definition of certain concepts used in this paper so as to guide its usage. This concepts are nation- building, education \& female and male gender.

\section{WHAT IS NATION BUILDING?}

Nation -building has been widely defined by many authors using different variables but the most appropriate to this topic is defined as 'the process whereby people transfer their commitment and loyalty from the smaller tribes, villages, and petty principalities to the larger control of political unit ${ }^{4}$. However Eliagwu posits that nation-building does not involve the transfer of 'commitments and 'loyalties' from narrow or parochial levels of ethnic groups to a larger political unit ${ }^{2}$. And that one cannot as a matter of identity relinquish or transfer her identity because one is an Ibo or Yoruba, or Hausa. He therefore suggested vertical and horizontal dimensions, that the vertical dimension of the nation-building is that members of the polity must progressively accept the legitimacy and the necessity of a central government and the identification with the central government as a symbol of the nation ${ }^{4}$. The horizontal dimension of nation- building involves the acceptance of other members of the civic body as equal fellow members of a 'corporate' nation that is recognizing the rights of other members to a share of common history, resources, values, and other aspects of the State buttressed by a sense of belonging to one political community ${ }^{5}$. From these two perspectives, Agi believes that the horizontal dimension applies to nation-building than the vertical dimension. She therefore defines nation-building as the process of creating unity and a sense of belonging among heterogeneous group in a state involving attempts at integrating the various groups in order to build a 'nation' out of the state ${ }^{6}$. In a nutshell, nation-building emphasizes the unity of both the male and the female and their integration into the central body as a nation with common ideas, visions, \& loyalty ${ }^{7}$.

From the above definitions, nation-building in the context of this paper requires that every member of a nation must be educated to have a sense of belonging, commitment, loyalty to the central body and must protect the national interest as well as be integrated into the central body irrespective of gender sexes, tribe or religion of individual member of the society..

\section{THE CONCEPT OF FEMALE GENDER}

The concept of the female gender is biologically recognized as the opposite sex of the male gender. According to sociologist, the word female or the concept of being a woman is considered to have more challenges, due to society not only viewing women as a social category but also as a felt sense of self, a culturally conditioned or constricted subjective identity ${ }^{8}$

The term "woman" has chronically been used as a reference to and for the female body; this usage has been viewed as controversial by feminists in the definement [sic] of "woman". The above view of the social identity theory can be viewed from perspective of the Bible. The Bible suggests that the female gender came out of the male's rib hence she is created to be his helpmeet ${ }^{10}$. The Bible further suggests that both the male and the female gender should be one in order to carry out procreation expansion, exploitation and capability to govern the whole earth ${ }^{11}$. In view of this, man and woman, needs to work hand in hand in order to build the nation.

However, Bible portrayed the man and the woman as equal in the role in which they are to partake in the world affairs. The bible claimed that they were both put in the Garden of Eden to keep it because Eve was part of Adam, inside him when the instruction was given to him by God. ${ }^{12}$ It was therefore assumed that women are subjective to men. Hence the relegation of women in the society.

The Traditional African Society also believe in the equality of the female and male gender in the roles assigned to them though based on their biological differences. From close observation, the African woman has been contributing socially, economically and politically to the development of her home, the community and the environment in which she lives. Women in Yoruba land are trained for motherly roles such as honesty, loyalty ,patriotism and chastity and are impacted to them from birth in form of traditional ethos, ethics and cultural values for the benefit of the society hence the Yoruba adage says "Ile la ti nko eso rode" meaning charity begins at home ${ }^{13}$ Consequently, in the pre-colonial era, there were female Obas, Iyalodes, Priestesses and

\footnotetext{
${ }^{4}$ Taifel, H \& Turner, J.C., "'The_Social_Identity_of_Inter group_Relations_'in S. Worches \& W.G. Austin (eds) The Psychology of InterGroup Relations. (Chicago: Nelson Hall, 1986). Pp. 7-24

5 ibid

${ }^{6}$ ibid

${ }^{7}$ Taifle H. Turner, op cit p. 25

${ }^{8}$ Gender Trouble: Feminism and the Sub-Version of Identity. Thinking Gender. (New York \& London: Routledge, 1990$)$ P.12

${ }^{9}$ ibid.

${ }^{10}$ King James Version,,$\underline{\text { The Holy Bible-Genesis chapter } 1 \text { verse 18. }}$.[Dallas:Jet Move InternationalLimired,2004]p.5

11 ibid

${ }^{12}$ King James Version, The Holy Bible op cit p.5

${ }^{13}$ Oral interview collected from Madam Julianah Agunloye,aged 96years old ,a devout christian at Idoani,on 12/07/2011. 
slave traders such as Eye-Aro in Akure, Yeye Lobun of Ondo, Moremi Ajasoro, Efunsetan Aniwura and others ${ }^{14}$ According to Western Philosopher, Michael Foucault

"...humans are the object of power which is not an institution or structure, rather it is a signifier or name attributed to "complex" strategically situation" because of this "power" is what determines individual attributes, behaviours etc and people are a part of an ontologically epistemologically constructed set of names and labels, such as being female characterizes one as a woman and being a woman signifies one as weak, emotional and irrational and is incapable of actions attributed to a "man""15

Consequently, the mind of the female child is developed as a woman to play the role of a woman as mothers, home-builders, decision-makers as well as religious leaders so as to preserve the traditional custom for the development of the community16. Conversely the mind of the male child is trained to be the provider for the home, the defender of the traditional ethos and the leader of the Community.17 From this background, the female becomes attached to these traditional roles until the Colonial era when the British Colonial masters introduced western ideology which relegated Nigerian women to the background in the affairs of the nation. Only few exceptional women that free their minds from the European's view on women were able to break the barrier of stereo-typed functions attached to her during the Colonial period.. They were able to contribute to the development of their communities because they had acquired western education which they combined with their understanding of the pre-colonial roles of Nigerian women as part of policy \&decision makers.to break the barrier. Among such females were Mesdames, Wuraola,Esan and Funmilayo Ransome Kuti at Abeokuta, Odukogbe, Ogunlesi at Ibadan ,Margaret Ekpo in Aba and Mallama Sawabo of Northern Nigeria18. They crossed the barrier to venture into the male assigned and dominated roles due to the economic ,formal \& informal educational power.

Religiously, it was the failure of the female gender to resist Satan that changed her role to that of subservient to the male gender19. Thus the male became the head and the provider for the family while the female became the mother to be ruled by the husband who would seat to keep the home. This is to say that it was indiscipline that relegated women to the background, it was not the original purpose of God for the female gender to be subjective to the male gender ${ }^{20}$ Consequent upon the inability of the woman to resist the devil, male gender became the Lord over the female gender hence the role assigned to them by the society.

From the above discussion, the role assigned to female formed the basis upon which the female idea of her contribution to the community and nation was shaped. This was the trend during the Colonial period in Africa and Nigeria in particular. The British overlords in Nigeria had different perspective of female gender roles from that of Nigerian traditional roles where female members of the society were part of policy and decision-making.

\section{THE CHANGING ROLES OF FEMALE GENDER IN NIGERIA:}

The British Colonial era relegated the roles assigned to women to virtually a chattel of their husbands21. The Nigerian women who in the pre-colonial era were ,the Omu, Iyalode,Traditional Rulers and Community Leaders e.g . Oueen Amina,Moremi Ajasoro,Efunsetan Aniwura,Madam Tinubu were regarded as weaker vessels. The Victorian era in Britain believed that it was unwomanly for a female to show a possession of brains hence women were to be seen and not to be heard.22They were regarded as parts of their husbands' furniture. But through the transforming influence of education females in Britain agitated for a reversal of their roles to the nation. By the $19^{\text {th }}$ century, women took bold steps to break the barrier, for instance, George Elliot took a man's name to conceal her sex and Bronte at first wrote under the pen names taken to represent men.23 But by the end of the century, better education and wider opportunities enabled the women to progress above fiction as many women became novelists ${ }^{24}$. Gradually, women ventured into Sociology, travel, religion, and art, that modern women like Mrs. Webb, Freyl Start, Evelyn Underhill started to win recognition on their own merit.25 Before women were allowed to vote in Britain, Mrs. Pankhurst had to head an organisation which organized violence called the 'women Social Political Union ${ }^{26}$. They went berserk, broke shop windows, and attack prominent members of the Government with whips, and chained themselves to railings in front of the House of Commons and to the Strangers' Gallery in the House ${ }^{27}$ They were imprisoned for their actions so they went on hunger strike until they were 'forcibly fed ${ }^{28}$ Consequently, a bill was passed that was nicknamed 'Cat \&Mouse' under which a prisoner on hunger strike would be released temporarily until he has sufficiently recovered to serve his jail term ${ }^{29}$. The collective action of these eminent influential women that were jailed led to a prison reform. In addition, the women played a prominent role in the 1914 World War by inducing the Government to grant women the franchise in 1918 after the end of the war ${ }^{30}$ Initially, the franchise was given to women with a property qualification and over the age of thirty but was subsequently changed in 1928 to enable women to having equal right with men at the age of twenty-one as a resident for a period of six month in a place. The first woman that was elected was an Irishwoman called Comtess Markieviez who did not seat in the

\footnotetext{
${ }^{14}$ NAA Ondo Province, oral interview collected from Mama Fadoju ,aged c87years old,at Akure,on17/05/2011.

${ }^{15}$ Tong, Rosemarie, Feminist Thought: A more Comprehensive Introduction/ (Romarie Tong, Boulder, Colo, West View Press, 2009 ). p.4.
} 
Parliament but Lady Aston became the first woman to seat in the Parliament ${ }^{31}$. Britain therefore granted equal and universal Suffrage giving political power to the female educated Working classes who have control over elections. This formed the basis of the dominant parties in British polity-Conservative, Liberal and Labour Parties $^{32}$. During the war, women started to take the place of men in factories, and occupations earlier reserved for men, on the land, the women also drove trains, acted as postmen, and gradually in all ramifications of life, women helped to set men free from work reserved for them in Britain 33Consequently in the 20th century, women in Britain instigated the Government to effect changes that brought equality to female and male gender. Women were granted full citizenship, boys and girls were given equal education from the state and the females can enter many professions that were hitherto reserved for men. The discrimination of women improved tremendously. Subsequently, the Victorian dresses of long heavy, tight dresses with little exercises changed to the modern woman who are now wearing short comfortable clothes and join in every form of sports or exercises $^{34}$. The emancipation of women in Britain was engendered by the educated women in that country. Likewise, in the 1960s, the women Liberation Movement started to champion the course of female gender emancipation to remove the biases against women and to advocate for equality of female with the male genders.

\section{THE IMPORTANCE OF FEMALE EDUCATION IN THE NATION-BUILDING}

Many Sociologists such as Margaret Mead, Robert Connell and Michel Foucalt believes that education like culture ,language and biological characteristics shapes the roles of female and male gender.

As earlier stated, the British Colonial Government due to the cultural value at home which regarded women as a weaker vessel transferred these idea to Nigeria thereby inhibiting the roles of Nigerian women as nation-builders .But the emancipation of women in Britain also found its way of expressing itself in Nigeria as a result of education being an agent of transmission. Thus educated women in Nigeria like Funmilayo Ransome-Kuti became the first woman to drive a car and Margaret Ekpo, were able to challenge the British Colonial Government on imposition of taxes on women and the political rights of women in Nigeria ${ }^{35}$ Funmilayo Kuti in her emancipation of women was molested by the British Colonial Government; her passport was seized to prevent her from attending a conference in London, on the rights of women ${ }^{36}$ She and Mallama Sawabo were imprisoned in Nigeria for political activities which the government perceived as an incitement of the masses against the government. As a result of education Miss Adunni Oluwole was able to form a Commoners Party and contested for a regional election in the old western region in $1959^{37}$. It is a fact that women constitute the largest number of the population, mobilizes in the political arena, producers of food items, and other economic products, the most found in churches, mosques \& traditional centres, yet their activities remained passive just because they have been indoctrinated into the British Colonial legacy. They lacked the knowledge of the feat performed by women in the pre-colonial period because they were not given informal education The importance of female education cannot be over- emphasized in the emancipation of women because it is one of the tools she can use to free herself from gender inhibitions and prohibitions placed on her by the society. 38 From the historical perspective, the female is forced by the laid down societal roles to adopt or adapt them as her standard of living dogmatically. She believes that it is the norm of the society for the husband to violate, oppress, enslave and exploit his wife. 39 Thus, the females having adapted to the notion that they are inferior to the male found it daring and unwomanly to compete with men in politics, Obaship, priesthood and in the manufacturing industries, In fact until recently, the female gender had been passively contributing to national development either in the political, social \& economical aspects. She is definitely not regarded as an integral part of policy and decision-making which are the essential ingredients of nation-building. This has accounted for the reasons that no female gender in Nigeria has been elected or appointed to high political offices in Nigeria as a President, Governor, Party Chairman, Senate President, Central Bank Governor, Head of Service, Secretary to Government, Group Managing Director of N.N.P.C., or as, a Social Critic or a Religious leader be it Christian, Muslim or Traditional religionist.40 It is true that women constitute the largest number of the population but education of the female is highly fundamental to the expression and assertion of her potentials as a woman to control, to influence, and to be an integral part of her society. With sound education, no field of human endeavour would intimidate her, she would only see them as one of the challenges she is capable of overcoming. Hence, she would be happier, satisfied and fulfilled as one of the nation-builders.

For the females to be parts of nation-building, their activities should rise above the local level to the federal government level as part of decision-makers and implementers of decision such made. As earlier stated in Britain, education played a crucial role in making the British women to be integrated in their society, this to a large extent transformed Britain from State-hood to Nation-hood .Globally, the women Liberation Movement cut across the World like hay fire, transforming the world into a better society through peaceful co-existence , unity in diversity, sense of belonging and integration of various nations especially the females groups 41 .In 1995, there was a World Conference of women where there was a convention that every nation that give assent to the bill must give $30 \%$ of political appointments to women ${ }^{42}$. Many nations including Nigeria gave their assent to the CEDAW ( The Convention to Eliminate All Forms of Discrimination Against Women) adopted by 
the United Nations in 1979, but only few of these nations have translated it to concrete action. Nigeria is one of the nations that has not translated it to concrete actions because the number of women in appointive and elective positions at the Federal level is less than $30 \%$.

The education of female gender is essential to enable her be the principal agent that would validate her status in the society as entrenched in the assent signed by different Countries in favour of women. It is education that enables women to cultivate the habit of courage, strength, knowledge and a sense of cultural and spiritual values. Education is the potent weapon to wipe out ignorance, inferiority complex. Education is the instrument to impart a sense of patriotism in the female gender so that she would develop all-round physically, socially, spiritually, mentally. This will enable women to uphold the ideals and make meaningful contribution to the society which she rightfully belong.

Furthermore, education in its transforming and reforming manner should be formal and informal training of the female child so that she could have the all-round development. These trainings will inculcate in her the sense of traditional values that will develop a sense of belonging, be conversant with the tradition of her community and has sifted respect for the culture. She would eventually appreciate the common values, beliefs, and the benefits which politics entails. Furthermore, she would be able to assess herself to the extent of being able to avoid what is necessary to discard thereby overcoming some in-built behaviours that are not acceptable to the nation such as ethnicity, tribalism, nepotism, embezzlement, thuggery, prostitution, and other anti-social behaviours. She would then be able to integrate successfully and properly in the nation and take her rightful position. This will enable her to realize her ambition either as political, economic or spiritual leader because she would have been matured for the position. Moreover, she would have overcome both aggressiveness, mental and emotional stress which could inhibit her from getting to leadership position or remove her from leadership position . On the other hand, Professor Dora Akunyili, Dr. Ngozi Iweala, performed at higher level than their male counterparts because of the level of their education. Akinyuli stayed with her grandmother hence the reflection of informal education in her passion for honesty, fight against fake drugs \&the laundering of Nigerians image.44 The level of their education and exposure had prepared them for the divergent demands of office.

Another area where education of the female is important to Nation-building is the area of upholding the Constitution of the nation, consideration for others and the refining of individual's mind, decency and decorum. These democratic cultural traits are clearly differentiated among the well- educated female and male members of the National Assembly. For instance, Abike Dabiri - Arewa is coping successfully with the challenges at the House of Representatives. Education is a tool that enhances the female gender to value the importance of democratic culture. The democratic culture involves the nation's philosophy and ideology, sense of dignity of labour, moral uprightness as well as respect for the right of every citizen in order to maintain its continuity in the nation. In the field of economy, education is another potent tool for the female gender to use for sound economic foundation as it prepares her for career opportunities in various fields such as Medicine, Law, Engineering, Sciences and other fields where her services would be highly remunerated. The career provides her with the opportunity to become a responsible national leader in any sphere of national life. In addition, the career provides her with a sound philosophy and ideology of nationalism which crave for inspiration, aspiration and pride of citizenship among the members of the nation. This is because economic interest and exchange engenders social and political interaction.

The ideology of many nations has become one indivisible, strong and virile nations therefore for it to be achievable, the nation must give the right education to her citizen who would be bold enough to challenge the ills of the nation. Also, she would be bold enough to execute programme, take action that would help the nation to achieve her goals thereby uplifting the nation. As said earlier on, female is the principal agent of transmission, so when you educate a female, you have educated the nation, The education of the female is a potent weapon to foster unity in diversity especially in a country of artificial British Colonial Government creation like Nigeria. Education of the female encourages inter-tribal and inter- cultural marriages and this would help to bind the nation together in brotherhood through the offspring. There would also be inter-mixture of culture, language, tribe, ethnics, and religion. Gradually, the nation would change from projecting ethnic or tribal identity to claiming - national identity which is the essential ingredient of nation-building. The female as mothers would bring their experience to bear on building the nation. Fortunately, education produces generation of enlightened citizens; education would help to increase the number of educated women who would be claiming their rights both in custom, politics, economic and social life. Consequently, there would be eradication of all restrictions and prohibitions working against her from having equality with her male counterpart. Through education, many of the vices militating against women such as maternal mortality, violence against women, rape, childmarriages, women-inheritance as part of husband's property, sexual harassment and the drinking of hemlock to prove her innocence during the demise of her husband will be eradicated. In a nutshell, female education is the fastest way of integrating the society because of her reproductive system she is uniquely empowered to influence others in the building of a strong, united and a virile nation. 


\section{Conclusion}

This paper has traced the definitions of the concept of nation building and female gender, explained the different ways by which religion, tradition and the British Colonial Government have put inhibitions, prohibitions and restrictions on the female gender in Nigeria hence the differential roles played by female and male genders in the same nation. The differential roles have not only brought inequality among them but have hampered the female from making visible and valuable contributions to nation-building. Also in this, the concept of nation-building was explained with a view to highlight the importance of education to help establish it. The paper therefore proceeded to trace the transforming influence of education to nation-building in Britain and dispersal of the right of the female through education to other parts of the world. The importance of education as a mirror through which the female can see and overcome those vices militating against her were discussed.

\section{Recommendation}

Finally, it is a fact that the importance of education to nation-building is immeasurable especially when it is given to the female gender of the nation. It has a way of stabilizing the polity by harnessing the man and material resources for the mutual respect, understanding and cooperation with one another and for peaceful coexistence. It is therefore hoped that the government must handle the issue of education by budgeting adequately for education of her teaming population with high percentage of women. Education must be affordable and be within the reach of the average citizen. The government in its bid to provide education physically, socially, and economically for all must ensure that; sex, social status, economic conditions geographical location should in no way be excuses for discriminatory provisions of educational opportunities. Therefore, Government should increase the number of public tertiary institutions than the private institutions. The approval of private universities and colleges of education is a flagrant violation of the declarations of the Federal Government on Education for All (E.FA). In its effort to provide efficient education, Government should critically re-assess the school curricula at all levels of educational institutions. It is highly essential to provide education that would train the mind of her citizens in civic and historical events to enable the citizens to be conscious of the history of the nation so as to engender patriotism and sense of national consciousness. The teaching of religious studies should also be re-introduced to help develop strong moral character in the females like the Deborah and Esther of the Bible, Khadjat and Queen Amina of the Muslim, and Moremi and Oya in the traditional religion. Since the female gender is the greatest teacher and the closest to the family, she needs to be taught to extend her loyalty to the larger society. A woman has a way of uniting the family in a close-knit manner; she can transfer this attribute possessed by her to nation-building.

- Above all, parents at home must train both female and male gender to perform the same household chores. Parents must also give them equal consideration in all areas of human endeavour by giving them equal tasks and educational career. The school should also prohibit the categorization of subjects on gender basis. There should be free interaction among both sexes so that the gap of inequality would be bridged. Individuals should be allowed to develop independently and self-reliant through the inclusion of entrepreneurship programme from the elementary school to the University level. There must also be provision of financial assistance in form of business loan for those who wants to go into self-employment while Education loan for those who are financially incapacitated. They should be granted education loan to further their education. Consequently, egalitarian society will emerge where there would not be fear of discrimination which is a major obstacle to nation- building.

\section{Endnotes}

[1]. Ozumba G.O. et al, Nigeria Citizenship Education (Aba: Vitahs Books (1999) p. 112.

[2]. bid. p. 2.ibid.

[3]. ibid

[4]. ibid

[5]. King James Version, The Holy Bible- Genesis Chapter 2 verse 18 (Dallas: Jetmove Publishers, 2000)

[6]. Warner, G.T., The New Ground Work of British History (London: Blackie \& Sons Ltd. 1939) P. 902

[7]. ibid

[8]. ibid

[9]. ibid p. 916

[10]. ibid

[11]. ibid

[12]. ibid

[13]. ibid

[14]. ibid

[15]. ibid p. 975

[16]. ibid

[17]. Jennifer Maroach Bank \& Gayle Letherby, Introduction to Gender: Social Science Perspective (Essex: Pearson Longman, 2007) p.8

[18]. Nina Emma Mba: Nigerian Women Mobilized Women's Political Activity in Southern Nigeria 1900-1965. ( Lagos: Crucible Publishers Ltd, 1997) pp. 246-247

[19]. ibid p.255

[20]. ibid p. 281 